can expect to achieve a view of how vast this landscape is. There is a good coverage of the relevant literature and, having read the volume, readers can expect to see better which of the many roads confronting them is likely to deal with the particular issues that interest them.

JULIAN SAVULESCU

Sub-faculty of Philosophy, University of

Oxford

\section{GenEthics: technological intervention in human reproduction as a philosophical problem}

\author{
Kurt Bayertz, Cambridge, \\ Cambridge University Press, 1994, \\ 342 pages, $£ 45.00$
}

When faced with questions about the morality of genetic research, some scientists take refuge in discussing merely the feasibility of certain procedures. For example, following a lecture in which Nobel prizewinner James D Watson had defended the morality of offering genetic manipulation of embryos if a gene for homosexuality were to be discovered, one scientist remarked to me that the proper answer to the question was that the trait of homosexuality could not be governed by a single gene, hence it would never be possible to manipulate embryos in order to remove the characteristic. Watson had at least given his answer to the ethical question, and it was an answer which relied upon the principle of the individual's right to choose - in this case the potential parents' right to choose the nature of their offspring.

In GenEthics, Kurt Bayertz maintains that we have to think about the ethical issues surrounding genetic research before we are capable of carrying out the scientific procedures, and that we do not yet possess norms for dealing with these issues: 'Modern gene and reproduction technology has provided us with practical options which we are unable to evaluate using traditional norms and values' (page 303).

Moreover, the missing norms and values are not there waiting to be discovered - 'With the help of GenEthics, we have to create them' (page 188).

This quotation reflects the Sartrean flavour of Bayertz's views. He rejects what he calls 'substantialism' - the view that 'there exists a human substance which must be regarded as the epitome of the psycho-physical unity of the human being' (page 129), and which should be respected as holy, hence protected from interference by gene and reproduction technology. Basing ethical principles on human nature is impossible, because, since human nature changes over time, it cannot be precisely defined, and even if it could, it would be impermissible to conclude that we ought to treat it in such and such a way simply because it $i$ of such and such a nature. What we must do instead is focus on subjectivity - 'the human ability to distance oneself from one's environment' (page 204). Because we are rational, self-determining beings capable of controlling nature, we must take responsibility for decisions to change, or to fail to change, our own nature. The fundamental significance of human autonomy requires that 'only subjectivism can be accepted as the philosophical basis for a publicly binding GenEthics' (page 306). Nevertheless, the autonomy of potential parents is not to be given free rein in decisions about the genetic manipulation of embryos, since the individual principally affected is not yet autonomous. Its future autonomy must therefore be protected.

Bayertz's principal recommendations are as follows: individuals should be free to decide the number of children they have and the way in which they are conceived; this freedom does not include a licence to carry out genetic manipulation at will - 'A line has to be drawn at the point where technological intervention restricts the child in its right to self-determination and prejudices its course through life' (page 311); any intervention must be unequivocally in the interests of the individual on whom it is carried out, and interventions are permissible only if they have a therapeutic objective. Bayertz acknowledges the problems of definition associated with this final criterion - there may be individual cases where it is difficult to decide whether a characteristic should be classified as a disease. But this criterion would give some ammunition to anyone wanting to challenge Watson's view that there should be no constraint on parental choice.

Bayertz's conclusions are commendable. Yet it is not clear that they have not been, or could not be, derived from norms and values to which we already adhere. Respect for autonomy, tempered with concern for well-being, is already part of the currency in discussions in medical ethics. Moreover the theoretical assumptions behind the exercise can be questioned. How would it be possible to invent values? Surely values must be grounded in some aspects of human nature, and there are signs that Bayertz himself accepts this - in his rejection of hedonism as a guiding principle, and in his insistence on the centrality of subjectivity. Perhaps he could maintain that values are being invented if his recommendation were merely that ethical principles are to be determined by agreements arising from the free exercise of subjectivity But he wants to impose constraints upon what is permissible in the area of genetic manipulation. For example even if the free exercise of subjectivity reached agreement that genetic manipulation were permissible for non-therapeutic purposes, he would not endorse this 'invented' value.

The density of argument and the presentation of a variety of positions sometimes make it difficult to see exactly which view is Bayertz's own For example, on page 215 he says 'Human nature can therefore be worthy of protection, but it is no necessarily so: not when it restricts subjectivity, and obstructs its free unfolding'.

This appears to set up a false dichotomy which Bayertz later rejects: 'A strict separation of human subjectivity and human nature is actually only possible for analytical purposes; the real human being is not half "subject" and half "a part of nature"' (page 294)

This is a long and detailed book, peppered with quotations, some of which are from writers with whom a British readership may be unfamiliar Hence it is difficult for this reviewer to set Bayertz's book in its proper context. There is much interesting detai on the history of ideas - ideas concerning degeneration, eugenics, and conceptions of human nature though it is not always clear what role certain digressions play in the overall argument. As a work of moral philosophy, the book deserves a more detailed analysis than is possible in this short review.

ANNE THOMSON

Philosophy Sector, School of Economic and Social Studies, University of Eas Anglia 